\title{
The Mafic Potassic Intrusion of Pariquera-Açu, São Paulo, Brazil
}

\author{
José Moacyr Vianna Coutinho' (mlcout@osite.com.br), Eleno de Paula Rodrigues², José Vicente Valarelli \\ 'Departamento de Mineralogia e Geotectônica - Instituto de Geociências - USP \\ R. do Lago 562, CEP 05508-080, São Paulo, SP, BRA \\ '2aboratório de Geociências - UnG, Guarulhos, SP, BRA \\ ${ }^{3}$ (in memoriam)
}

Keywords: mafic intrusion, Pariquera-Açu, shonkinite, malignite.

\begin{abstract}
This paper describes the geological, petrographic, mineralogic and chemical characteristics of the mafic potassic intrusion of Pariquera-Açu (P-A), southern São Paulo. The studied rock assemblage comprises members of the high-K alkalic magma series. Nepheline, orthoclase and clinopyroxene are the essential minerals present in all samples examined microscopically. Olivine, biotite and magnetite are also present. Plagioclase is absent. The series range from nepheline syenite to alkali pyroxenite with strong dominance of shonkinites and malignites. Alkali diabase dykes were also sampled. The alkalic magma intruded Proterozoic phyllites along tensile fractures. The intrusion is conceivably shaped as sub-vertical ring dykes with internal occupancy of sub-horizontal magma sheets. Sharply discordant contacts and occurrence of low to medium angle sheets of shonkinite and of unstrained intrusion breccias, give support to the idea of a pipe-like magmatic body formed by ring-fracture, stoping of a roof slab and final magma injections. It is suggested that small degrees of partial melting of a phlogopite-bearing mantle peridotite could produce the high $\mathrm{K}_{2} \mathrm{O}$ magma responsible for the generation of the $\mathrm{P}-\mathrm{A}$ rocks.
\end{abstract}

Palavras-chave: intrusão máfica, Pariquera-Açu, shonkinito, malignito.

\section{RESUMO}

Este trabalho descreve as características geológicas, petrográficas, mineralógicas e químicas da intrusão potássica máfica de Pariquera-Açu (P-A), sul de São Paulo. A litologia estudada compreende membros da série magmática alcalina de alto K. Nefelina, ortoclásio e clinopiroxênio constituem os minerais essenciais presentes em todos os exemplares microscopicamente quantificados. Olivina, biotita e magnetita estão também presentes. Plagioclásio não foi encontrado. A série rochosa graduase de nefelina sienito a álcali piroxenito apresentando, porém, alta predominância de shonkinitos e malignitos. Foram também amostrados alguns diques de álcali diabásio. O magma alcalino introduziu-se em filitos proterozóicos ao longo de fraturas de tensão. Supõe-se que a intrusão tenha se realizado sob a forma de "ring dykes" subverticais com a parte interna ocupada por lençóis magmáticos subhorizontais. Contactos discordantes e ocorrência de camadas de shonkinito e brechas intrusivas a baixo e médio ângulo, reforçam a idéia de um corpo magmático na forma de "pipe" intrudido em fratura anelar provocando solapamento do teto e espaço para injeções finais de magma. Sugere-se que a fusão inicial em pequena proporção de um peridotito flogopítico do manto poderia resultar em um líquido magmático de alto $\mathrm{K}_{2} \mathrm{O}$, responsável pela formação das rochas de P-A. 


\section{INTRODUCTION}

The Pariquera-Açu (P-A) alkalic mafic intrusion is found at the locality of Pariquera-Mirim, $6 \mathrm{~km}$ ESE from the town of Pariquera-Açu in the southern part of São Paulo State, Brazil. Its geometric center is close to the intersection of coordinates $24^{\circ} 44^{\prime} \mathrm{S}$ and $47^{\circ} 49^{\prime} \mathrm{WG}$ (Figure 1).
The aim of the present paper is to bring out geological, petrographic and mineralogical information on the mentioned occurrence.

Geological investigation of the P-A intrusion started in the early eighties as a result of the study of aeromagnetic anomalies mapped in Southern São Paulo - East Paraná region. The P-A anomaly was interpreted by Ferreira and

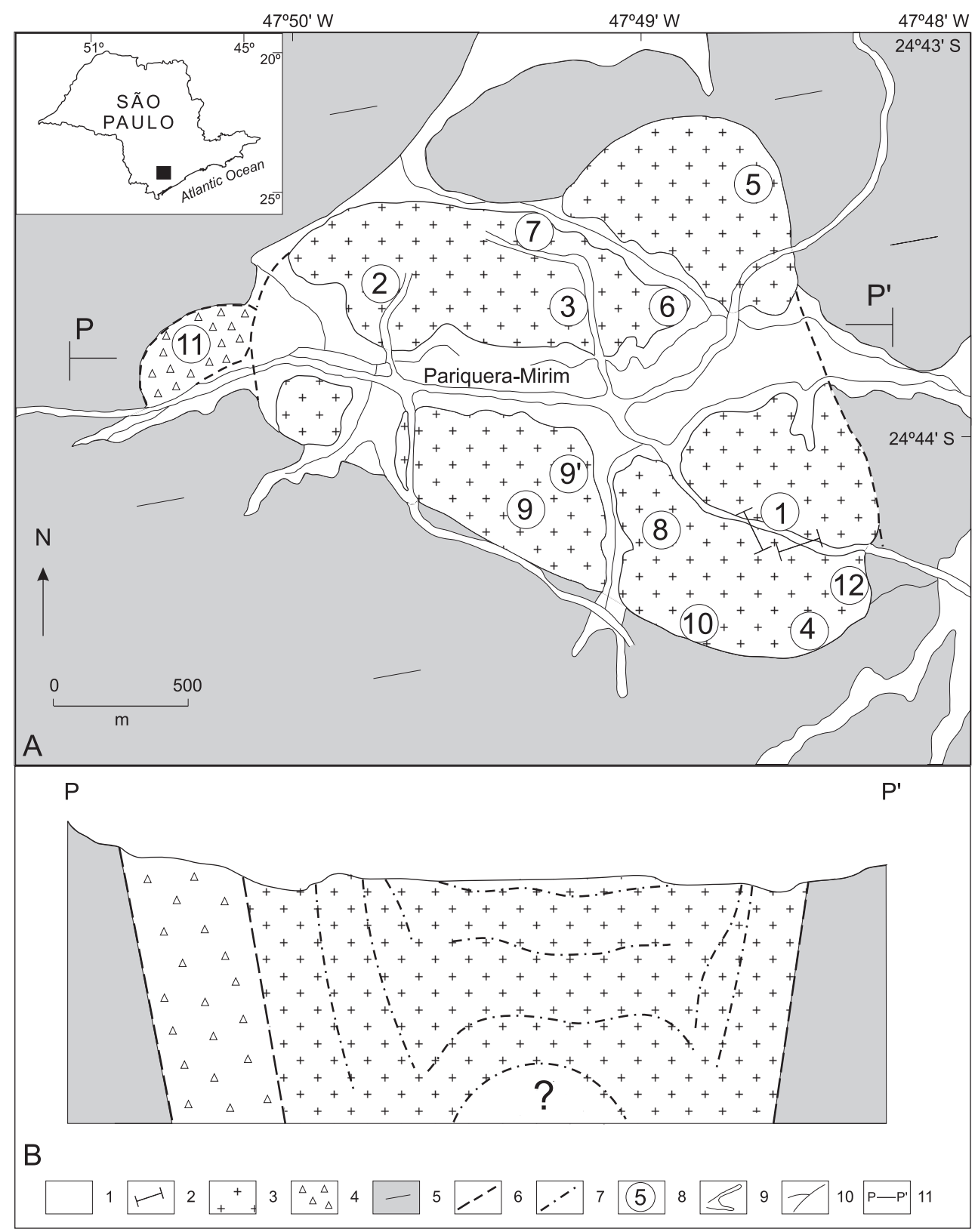

Figure 1. A. Geologic map of the mafic potassic intrusion of Pariquera-Açu (P-A). B. Theoretical cross section P-P'. 1. Alluvium cover along fluvial drainage. 2. Alkali diabase dykes. 3. Shonkinite, malignite and pyroxenite. 4. Contact breccia. 5. Country rocks (mainly phyllite). 6. Geologic contacts, hatched where inferred. 7. Presumed flow lines (in depth). 8. Location of sampled occurrences. 9. Roads. 10. Fluvial drainage. 11. Cross section direction. 
Algarte (1979) as a probable alcalic manifestation, a hint that was authenticated by field work in 1983. The occurrence had its geological, geophysical and concise petrographic features described by Ferreira et al. (1987). In 1998, Machado Jr. came out with age determinations for the P-A shonkinites, and Morbidelli et al. (2000) presented detailed chemical study of the P-A rocks as well as petrographic determinations and mantle source characteristics. Recently (2002) a hole was drilled that brought new petrographic data and interpretation to the intrusion behavior.

The original work was considered ready for publication since 1996. At that time, description of geological setting, petrographic systematics and mineral identification conflicted in several topics with those found in the more recent paper by Morbidelli et al. (2000).

\section{GEOLOGICAL FEATURES}

The intrusion is cordiform, its longest dimension running $3 \mathrm{~km}$ in the NW direction. Groups of metric to decametric boulders irregularly scattered throughout the area constitute the only fresh rock expositions found. They crop out in the midst of bush or grassland which grows on a rich residual soil, locally known as "terra do Aleixo". This dark brown clayey isotropic (latossolic) soil contrasts neatly with the yellow or pink podzolic soil derived from phyllite which constitutes the enveloping country rock of the intrusion. Such a contrast permits an accuracy of less than $200 \mathrm{~m}$ in tracing the intrusion contact on a geological map.

The P-A body occurs in a geomorphologically lowered terrain, a fact that can be attributed to the weak resistance that mafic rocks offer to physical and chemical weathering.

As a rule, the boulders expose a dark gray gabbroid rock whose modal variations are not discernible by the unaided eye. Only in one outcrop (Oc. 9), a slender, light-colored nepheline syenite vein was sampled. In addition, a few $20 \mathrm{~cm}$ thick half-weathered diabase dykes (Oc. 1) were also detected along a "terra do Aleixo" roadside exposure.

Except for the above cases, the P-A body outcrops exhibit remarkable macroscopic homogeneity. Pegmatites, veins, inclusions and evidences of deformation, metamorphism, metasomatism and contact metamorphism are not easily detectable. It is not impossible however that the deep "terra do Aleixo" soil is actually covering rock structures of low weathering resistance, such as fault zones, carbonatite venulation, bedding and xenolithic concentrations.

It is worth mentioning that at the Oc. 6 a "gneissoid" structure is observed. Here, a strong mineral orientation, set up by the piling of pyroxene plates in a low-angle attitude, indicates that crystal accumulation or flow processes were effective in the inner parts of the magma body at the time of the intrusion. In fact, samples taken from a hole located close to Oc. 6 well inside the P-A body, were recognized as shonkinite, pyroxenite and undeformed breccias in sheets and veins, positioned in a medium angle plunge. Otherwise, in some peripherally situated outcrops (Oc. 2 and 9) a subtle mineral orientation corresponds to the attitude of flattened, almost vertical boulders. Assuming that they remained more or less in place, their mineral orientation - a flow structure - should be parallel to the body's external shape, which suggests a steeply deeping centripetal surface (Figure 1).

The foliation in the surrounding phyllite is clearly discordant to the contact line and do not show signs of syn or post intrusion deformation.

Outside the mafic body and very close to its western contour (Oc. 11), breccia blocks speckle the south slope of a hill. They consist of deeply weathered quartz-rich fragments and matrix. This composition does not agree with that of the intruded rock and so the presence of such rock in the overall context remains unexplained.

The observed geological features are synthetized in Figure 1. The section P-P' is of course an idealized conception based essentially on field structural features.

The P-A body can be envisaged as cylinder or funnelshaped mass whose characteristics points towards a behavior that seems distinctive for most of the alkalic rock bodies around the world, that is: they usually constitute permissive intrusions characterized by small size, elliptic or round contour, vertical or sub-vertical contacts and, as a rule, do not deform the adjacent country rock (Sorensen, 1974).

\section{PETROGRAPHY}

\section{The pyroxenite-shonkinite-malignite- nepheline syenite series of the mafic intrusion}

The modes extracted from 11 specimens from PariqueraAçu are shown in the Table 1 and commented below.

In the modal diagram proposed by Le Bas (1977), most analyses taken from the P-A mafic body falls in the fields of malignite and shonkinite (Figure 2). In the classification of igneous rocks recommended by the IUGS (Streckeisen, 1976), the terms malignite and shonkinite correspond to foid syenites (mainly nepheline syenites) with colour indexes of 30 - 60 and 60 - 90 respectively, malignite being a mesocratic nepheline syenite and shonkinite a melanocratic one. These rocks consist essentially of the assemblage: salitic clinopyroxene-Na orthoclase, plus smaller amounts of nepheline, a turbid feldspathoidal aggregate, biotite, olivine and magnetite. Apatite is the normal accessory and kaersutitic hornblende plus secondary zeolites may appear in some thin-sections. 
Table 1. Modal (vol.\%) analysis of 11 rock samples from Pariquera-Açu. (*) Turbid material counted as foid is made up of analcite and nepheline plus varied amounts of orthoclase, zeolite and calcite. (**) Sh: shonkinite. Ml: malignite. Py: pyroxenite. NS: nepheline syenite.

\begin{tabular}{lccccccccccc}
\hline & \multicolumn{11}{c}{ Specimen number } \\
\cline { 2 - 11 } & $\mathbf{2}$ & $\mathbf{3}$ & $\mathbf{4}$ & $\mathbf{5}$ & $\mathbf{6}$ & $\mathbf{7}$ & $\mathbf{8}$ & $\mathbf{9}$ & $\mathbf{9}$ & $\mathbf{1 2}$ & $\mathbf{1 2}$ \\
\hline Orthoclase & 16 & 12 & 47 & 21 & 8 & 40 & 32 & 72 & 24 & 49 & 42 \\
Nepheline & 5 & 8 & 5 & 6 & 5 & 3 & 3 & 13 & 5 & 1 & 4 \\
Aggregate* & 10 & 7 & 6 & 16 & 3 & 8 & 8 & 2 & 5 & 10 & 7 \\
Albite & - & 1 & 1 & - & - & - & - & - & - & - & - \\
Analcite & 1 & - & - & - & 2 & - & - & $\operatorname{tr}$ & - & - & - \\
Biotite & 5 & 7 & 2 & 5 & 2 & 5 & 5 & 2 & 5 & 1 & 2 \\
Hornblende & - & - & 4 & - & tr & - & 1 & 2 & 1 & 4 & 3 \\
Clinopyroxene & 44 & 50 & 25 & 39 & 61 & 29 & 35 & 5 & 43 & 20 & 27 \\
Olivine & 11 & 10 & 3 & 6 & 12 & 4 & 6 & 1 & 7 & 6 & 5 \\
Apatite & 2 & 1 & 2 & 1 & 1 & 1 & 1 & $\operatorname{tr}$ & 1 & 1 & 1 \\
Magnetite & 6 & 4 & 5 & 6 & 6 & 10 & 9 & 3 & 9 & 8 & 9 \\
\hline Mafic index & 68 & 72 & 41 & 57 & 82 & 49 & 57 & 13 & 66 & 40 & 47 \\
\hline Rock name ${ }^{* *}$ & $\mathrm{Sh}$ & $\mathrm{Sh}$ & $\mathrm{Ml}$ & $\mathrm{Ml}$ & $\mathrm{Py}$ & $\mathrm{Ml}$ & $\mathrm{Ml}$ & $\mathrm{NS}$ & Sh & $\mathrm{Ml}$ & $\mathrm{Ml}$ \\
\hline
\end{tabular}

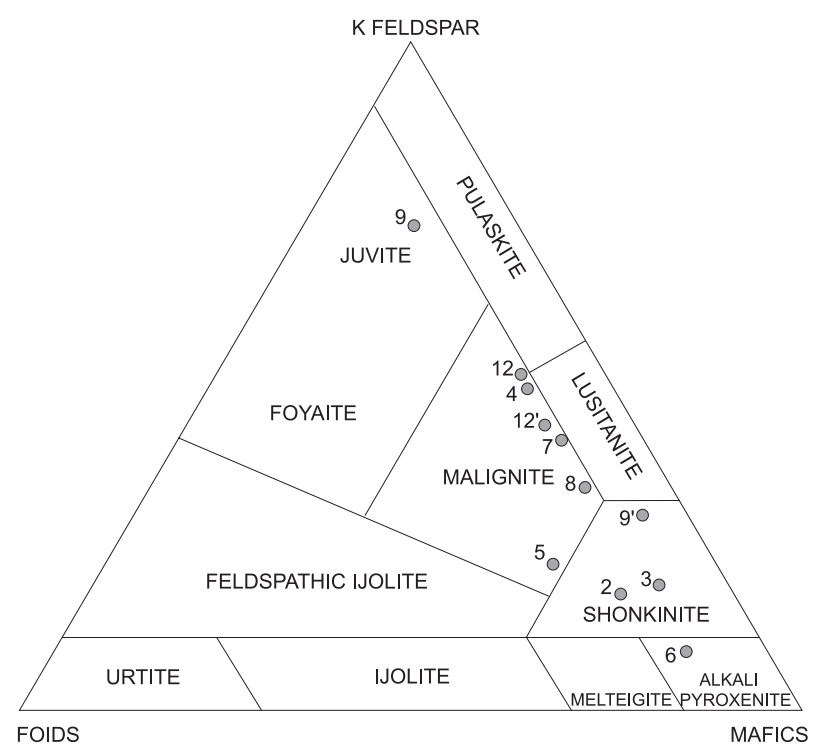

Figure 2. Modal diagram for the P-A rocks (Le Bas, 1977, modified).
The pegmatitic panxenomorphic nepheline syenite of Oc. 9 (Figure 3A) and the ultramafic alkali pyroxenite (or jacupiranguite) of Oc. 6 are the only two modal exceptions to the malignite-shonkinite dominance and may represent two extremes in the differentiation process.

The malignite-shonkinite rocks are massive, medium to coarse grained and exhibit a normal sequential texture (Figure 3B) made up by distinctly euhedral olivine, clynopyroxene, magnetite and apatite. Biotite is subhedral and orthoclase and feldspathoids are anhedral and interstitial. Two samples from Oc. 12 display a tendency for a porphyritic arrangement that is: millimetric clinopyroxene phenocrystals dipped in a fine-grained groundmass. A true shonkinite porphyry was detected in a sample from the borehole near Oc. 6. Here, euhedral millimetric augite and olivine phenocrysts are immersed in a very fine-grained biotite shonkinite flown matrix. The rock appears as fragments in a shonkinitic breccia. The alkali pyroxenite of Oc. 6 exhibits a cumulus texture built by heaped layers of clinopyroxene (Figure 3C). Since no complementary felsic layers were found and there is no full evidence for crystal settling, the nongenetic use of the term cumulus is here implied (Irvine, 1982).

\section{Breccia}

Thin sections study and filed x-ray diffractometry data in samples from Oc.11 helped to identify only quartz, kaolinite and goethite as rock constituents.

Despite the intensive alteration suffered by the rock, it was possible to detect in some fragments, textural and com- 


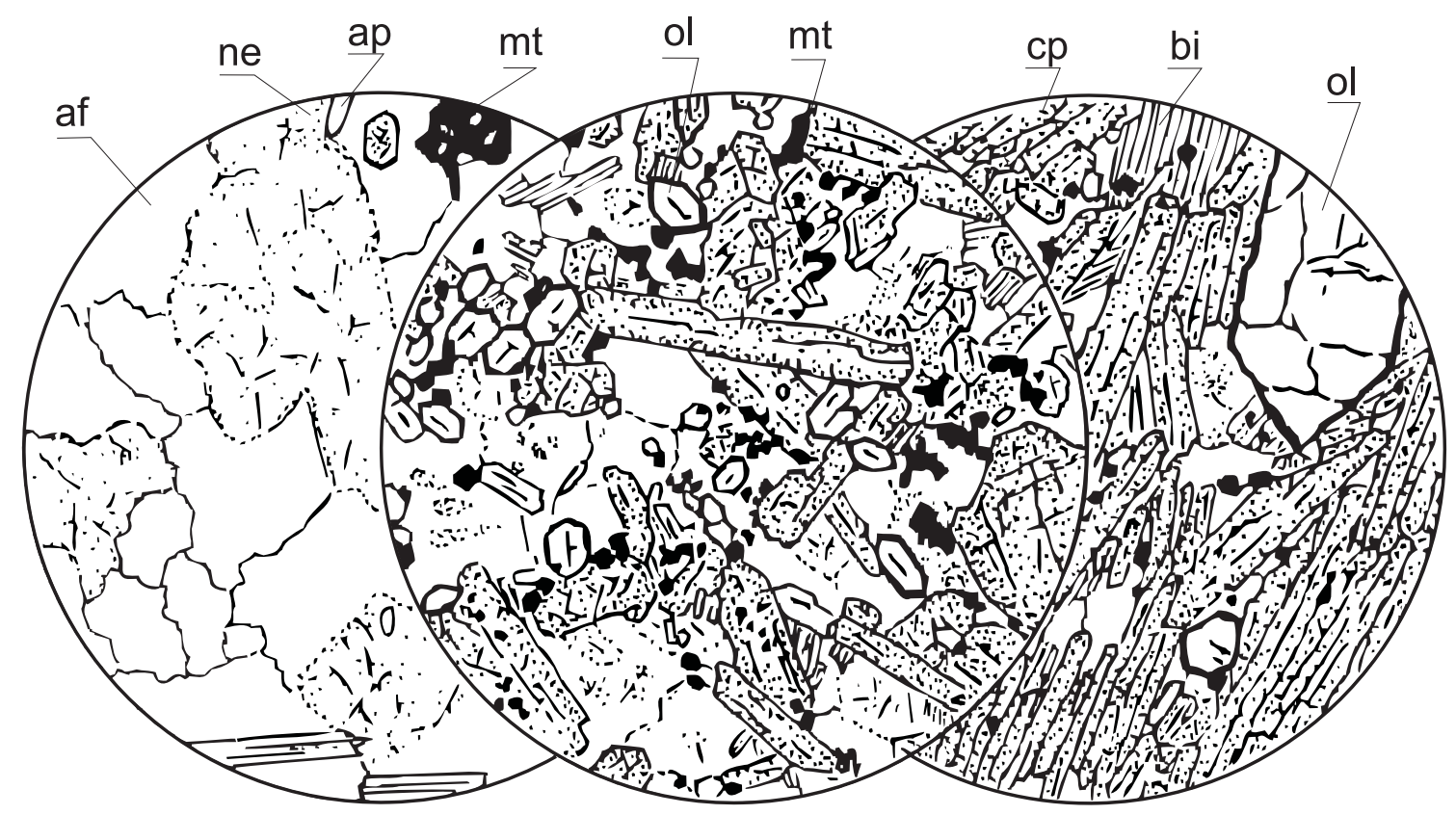

A

B

C

Figure 3. Mineralogy and textures found in P-A rocks. Field of view diameter: $1.5 \mathrm{~cm}$. A. Nepheline syenite. B. Shonkinite. C. Alkalipyroxenite. af: alkali feldspar; ap: apatite; bi: biotite; cp: clinopyroxene; $\mathrm{mt}$ : magnetite; ne: nepheline; ol: olivine.

positional evidences of a crushed preexistent quartzfeldspatic rock mass.

Several fragments are found included in quartzose material making up other equally brecciated fragments, cemented by more quartz and limonite. In some thin sections it is possible to spot late fractures and microfaults which seem to have developed during local tectonic event. Such compositional and structural evidence rules out genetic affiliation of the breccia to the neighboring mafic body. It is reasonable however to interpret it as a phyllite cataclasite produced by shearing at the intrusion contacts.

\section{Alkali Diabase}

The two slender dykes of Oc.1 can be described as products of alkali basic magmatism. No chemical analysis was carried on, due to its weathered condition. However, some petrographic details helped to assert its alkalic lineage.

Under the microscope, the rock exhibits intergranular texture. The main mineralogic composition is the usual one for diabases: labradoritic plagioclase laths (35\%); pale clinopyroxene (30\%); fine grained alkali feldspathic matrix $(25 \%)$; dendritic magnetite $(7 \%)$; products of weathering and/or deuteric alterations: clay minerals, carbonate, hydrobiotite, zeolite, goethite and amphibole (3\%). On the other hand, when the late crystallization assemblage is observed, it is noticeable the almost complete absence of quartz, the abundance of alkali feldspar and the presence of a blueviolet $\mathrm{Na}$ amphibole (riebeckite) replacing brown amphibole and clinopyroxene.

\section{CHEMISTRY}

Five chemical analyses of the main rocks from P-A were performed, and their results are given in the Table 2.

The chemistry of the P-A rocks is self-evident. It suffices to say that $\mathrm{TiO}_{2}$ is high and $\mathrm{K}_{2} \mathrm{O}$ predominates over $\mathrm{Na}_{2} \mathrm{O}$ until the last stage of the differentiation. The distinctly potassic character of the $\mathrm{P}-\mathrm{A}$ rocks $\left(\mathrm{K}_{2} \mathrm{O} / \mathrm{Na}_{2} \mathrm{O}\right.$ from 1.3 to 3.5 ) is in marked contrast with the real or inferred compositions of the mafic silicate rocks of neighboring Mesozoic intrusions. Ratios from three nearby alkalic-carbonatite intrusion occurrences support this idea:

1. Itapirapuã, northwest P-A, melanite malignite: $\mathrm{K}_{2} \mathrm{O} / \mathrm{Na}_{2} \mathrm{O}=0.5$ (Gomes and Dutra, 1970); 
Table 2. Analyses of rocks from Pariquera-Açu (wt \%).

DI: Differentiation index $=Q+o r+a b+n e+l c$ (Thornton and Tuttle, 1960).

Cl: Crystallization index $=a n+d i+f o+e n$ (Poldervaart and Parker, 1964).

\begin{tabular}{|c|c|c|c|c|c|}
\hline & \multicolumn{5}{|c|}{ Specimen number and rock name } \\
\hline & 6 & 3 & 5 & 4 & 9 \\
\hline & Pyroxenite & Shonkinite & Malignite & Malignite & Ne-syenite \\
\hline $\mathrm{SiO}_{2}$ & 47.29 & 45.20 & 45.36 & 47.25 & 56.03 \\
\hline $\mathrm{TiO}_{2}$ & 3.30 & 2.96 & 4.59 & 3.73 & 1.45 \\
\hline $\mathrm{Al}_{2} \mathrm{O}_{3}$ & 8.60 & 8.69 & 10.15 & 14.17 & 18.65 \\
\hline $\mathrm{Fe}_{2} \mathrm{O}_{3}$ & 2.49 & 4.62 & 5.68 & 6.40 & 3.35 \\
\hline $\mathrm{FeO}$ & 7.70 & 7.58 & 7.06 & 6.32 & 2.47 \\
\hline $\mathrm{MnO}$ & 0.19 & 0.24 & 0.23 & 0.22 & 0.07 \\
\hline $\mathrm{MgO}$ & 11.05 & 11.39 & 7.56 & 5.24 & 1.78 \\
\hline $\mathrm{CaO}$ & 16.06 & 13.31 & 10.82 & 9.28 & 2.31 \\
\hline $\mathrm{BaO}$ & 0.07 & 0.11 & 0.13 & 0.19 & 0.08 \\
\hline $\mathrm{SrO}$ & 0.06 & 0.09 & 0.10 & 0.14 & n.d. \\
\hline $\mathrm{Na}_{2} \mathrm{O}$ & 0.53 & 1.76 & 2.24 & 2.45 & 5.54 \\
\hline $\mathrm{K}_{2} \mathrm{O}$ & 1.88 & 2.26 & 3.70 & 3.26 & 7.26 \\
\hline $\mathrm{P}_{2} \mathrm{O}_{5}$ & 0.27 & 0.73 & 0.59 & 0.57 & 0.16 \\
\hline $\mathrm{Cr}_{2} \mathrm{O}_{3}$ & 0.12 & 0.16 & 0.10 & 0.04 & n.d. \\
\hline $\mathrm{H}_{2} \mathrm{O}^{+}$ & 0.38 & 0.81 & 1.54 & 0.63 & 0.23 \\
\hline $\mathrm{F}$ & 0.01 & 0.08 & 0.15 & 0.11 & 0.15 \\
\hline Total & 100.00 & 99.99 & 100.00 & 100.00 & 99.53 \\
\hline \multirow[t]{2}{*}{$\mathrm{K}_{2} \mathrm{O} / \mathrm{Na}_{2} \mathrm{O}$} & 3.55 & 1.28 & 1.65 & 1.33 & 1.31 \\
\hline & \multicolumn{5}{|c|}{ CIPW norm } \\
\hline Orthoclase (or) & 11.15 & 13.47 & 22.23 & 19.40 & 43.03 \\
\hline Albite (ab) & 4.50 & 5.29 & 9.17 & 20.88 & 27.52 \\
\hline Anorthite (an) & 15.61 & 9.24 & 6.85 & 18.26 & 4.62 \\
\hline Nepheline (ne) & - & 5.27 & 5.47 & - & 10.56 \\
\hline Diopside (di) & 41.26 & 36.07 & 32.83 & 18.97 & 3.95 \\
\hline Hedenbergite & 9.00 & 6.13 & 1.58 & 0.69 & - \\
\hline Enstatite (en) & 0.47 & - & - & 2.18 & - \\
\hline Ferrosilite & 0.12 & - & - & 0.09 & - \\
\hline Forsterite (fo) & 5.64 & 8.37 & 2.79 & 1.56 & 1.84 \\
\hline Fayalite & 1.56 & 1.80 & 0.17 & 0.07 & - \\
\hline Ilmenite & 6.29 & 5.67 & 8.86 & 7.13 & 2.76 \\
\hline Magnetite & 3.62 & 6.75 & 8.37 & 9.34 & 4.00 \\
\hline Hematite & - & - & - & - & 0.60 \\
\hline Apatite & 0.63 & 1.73 & 1.41 & 1.36 & 0.38 \\
\hline Chromite & 0.18 & 0.24 & 0.15 & 0.06 & - \\
\hline Fluorite & - & 0.03 & 0.21 & 0.12 & 0.29 \\
\hline DI & 15.65 & 24.03 & 36.87 & 40.28 & 81.11 \\
\hline $\mathrm{Cl}$ & 62.98 & 53.68 & 42.47 & 39.41 & 10.41 \\
\hline
\end{tabular}


2. Jacupiranga, north P-A, alkali pyroxenite (jacupiranguite): $\mathrm{K}_{2} \mathrm{O} / \mathrm{Na}_{2} \mathrm{O}=0,2$ (Washington, in: Johannsen, 1938);

3. Juquiá, northeast P-A, olivine clinopyroxenite: $\mathrm{K}_{2} \mathrm{O} / \mathrm{Na}_{2} \mathrm{O}=0.1$ to 1.2 (3 analyses in Beccaluva et al., 1992). Also $<1$, as inferred from pyroxenite and ijolite modal analyses (Born, 1971).

The P-A alkalic magma series plot in the limits of $\mathrm{K}$ and high- $\mathrm{K}$ areas of the $\% \mathrm{~K}_{2} \mathrm{O}-\% \mathrm{Na}_{2} \mathrm{O}$ diagram of Middlemost (1975).

It may also be noted that the differentiation index, as would be expected, increases toward the nepheline syenite in a tendency inversely proportional to the crystallization index.

\section{MINERALOGY}

Mineral chemical compositions were obtained at the "Laboratório de Microscopia Eletrônica do GMG/USP". The equipment employed is a Jeol JXA 8600 superprobe. Microscopic characteristics and genetic inferences were compared with informations given by Deer, Howie and Zussman (1963).

\section{Clinopyroxene}

The P-A clinopyroxene habit shows little variation throughout the intrusion. As seen in thin section, they tend to occur as euhedral (001) laths flattened on (100), with average length of $1-3 \mathrm{~mm}$ and up to $5-7 \mathrm{~mm}$ in porphyritic (Oc. 12) and coarser grained specimens. Their color is normally yellowish green or pale brown. The last named tone, indicative of $\mathrm{Fe}$ and/or Ti enrichment, may replace totally or partially the crystals, specially at the borders.

Microprobe analyses of representative clinopyroxenes from P-A rocks are listed in the Tables $3 a$ and $3 b$.

$\mathrm{The} \mathrm{Mg}: \mathrm{Fe}: \mathrm{Ca}$ ratios extracted from the chemical analyses of Table 3a as well as the optical informations of Table 3b, make it clear that the P-A clinopyroxenes are represented solely by salite. They parallel the salite data recorded in Deer, Howie and Zussman (1993). It is also evident that both, salite and accompanying biotite (Table 5), become more Fe-rich in the nepheline syenite vein of Oc. 9. Nevertheless there is only limited replacement of $\mathrm{Mg}_{\text {by Fe}}{ }^{+2}$ in these salites. In addition, Table $3 b$ shows that the salite's brown border is $\mathrm{Si}-\mathrm{Na}-\mathrm{Fe}$ richer than the core, as expected in the clinopyroxene composition of an evolved interstitial alkaline liquid. On the other hand, the Ti content commonly associated with the brown pyroxene zones, is here reduced.

Table 3a. Microprobe chemical analyses of clinopyroxenes from Pariquera-Açu (wt \%).

\begin{tabular}{lcc|cc}
\hline & \multicolumn{2}{c|}{$\begin{array}{c}\text { In nepheline syenite } \\
\text { (7 analyses) }\end{array}$} & \multicolumn{2}{c}{$\begin{array}{c}\text { In shonkinite } \\
\text { (9 analyses) }\end{array}$} \\
\cline { 2 - 5 } & Range & Average & Range & Average \\
\hline $\mathrm{SiO}_{2}$ & $47.54-50.91$ & 49.08 & $47.79-51.47$ & 49.60 \\
$\mathrm{TiO}_{2}$ & $1.20-3.11$ & 2.07 & $0.72-2.52$ & 1.72 \\
$\mathrm{Al}_{2} \mathrm{O}_{3}$ & $2.57-5.45$ & 4.02 & $2.03-5.66$ & 3.80 \\
$\mathrm{FeO}$ & $8.73-10.75$ & 9.54 & $6.17-7.81$ & 6.80 \\
$\mathrm{MnO}$ & $0.10-0.43$ & 0.26 & $0.00-0.25$ & 0.15 \\
$\mathrm{MgO}$ & $10.27-11.46$ & 11.06 & $12.03-14.12$ & 13.17 \\
$\mathrm{CaO}$ & $21.63-22.04$ & 21.78 & $21.49-22.83$ & 22.20 \\
$\mathrm{Na}{ }_{2} \mathrm{O}$ & $0.73-1.05$ & 0.83 & $0.43-1.02$ & 0.67 \\
$\mathrm{~K} O$ & $0.00-0.01$ & - & $0.00-0.11$ & 0.02 \\
$\mathrm{~F}$ & $0.00-0.31$ & 0.09 & $0.00-0.36$ & 0.12 \\
$\mathrm{BaO}$ & $0.00-0.41$ & 0.07 & $0.00-0.27$ & 0.07 \\
$\mathrm{SrO}$ & $0.00-0.00$ & - & $0.00-0.00$ & - \\
$\mathrm{Cl}$ & $0.00-0.05$ & 0.01 & $0.00-0.05$ & - \\
\hline $\mathrm{Mg}$ & \multicolumn{5}{c}{34.48} & & 39.98 \\
$\mathrm{Fe}$ & 18.70 & & 48.44 \\
$\mathrm{Ca}$ & & 48.81 &
\end{tabular}


Table 3b. Microprobe chemical analyses of a zoned clinopyroxene from Pariquera-Açu shonkinite and some related optical data (wt \%).

\begin{tabular}{|c|c|c|c|}
\hline & Core & Middle & Border \\
\hline $\mathrm{SiO}_{2}$ & 49.38 & 50.35 & 51.14 \\
\hline $\mathrm{TiO}_{2}$ & 1.80 & 1.29 & 1.20 \\
\hline $\mathrm{Al}_{2} \mathrm{O}_{3}$ & 4.33 & 3.15 & 2.45 \\
\hline $\mathrm{FeO}$ & 6.18 & 6.43 & 7.57 \\
\hline $\mathrm{MnO}$ & 0.00 & 0.04 & 0.25 \\
\hline $\mathrm{MgO}$ & 13.77 & 14.12 & 12.65 \\
\hline $\mathrm{CaO}$ & 22.31 & 22.59 & 21.83 \\
\hline $\mathrm{Na}_{2} \mathrm{O}$ & 0.45 & 0.58 & 1.02 \\
\hline $\mathrm{K}_{2} \mathrm{O}$ & 0.11 & 0.00 & 0.06 \\
\hline $\mathrm{F}$ & 0.02 & 0.18 & 0.00 \\
\hline $\mathrm{BaO}$ & 0.23 & 0.02 & 0.00 \\
\hline $\mathrm{SrO}$ & 0.00 & 0.00 & 0.00 \\
\hline $\mathrm{Cl}$ & 0.05 & 0.02 & 0.00 \\
\hline Total & 98.63 & 98.77 & 98.17 \\
\hline$\overline{n_{x}}$ & 1.691 (av.) & - & 1.702 (av.) \\
\hline $\mathrm{n}_{\mathrm{z}}$ & 1.716 (av.) & - & 1.725 (av.) \\
\hline $\mathrm{Z} \wedge \mathrm{C}$ & $45^{\circ}-47^{\circ}$ & - & $47^{\circ}-50^{\circ}$ \\
\hline $2 V_{z}$ & $45^{\circ}-58^{\circ}$ & - & $52^{\circ}-62^{\circ}$ \\
\hline
\end{tabular}

\section{Alkali Feldspar}

The common habit of alkali feldspars in the P-A rocks is of clear, untwinned, anhedral crystals grown in the voids left by the crystallization of the mafic minerals. String microperthite appears irregularly in some alkali feldspar areas.

Myrmekitic nepheline inclusions in feldspars are frequent and Baveno twinnings are sometimes seen. There are also samples in which turbidity developed in feldspar and feldspathoids. The (100) thin cross-hatched pattern, typical of anorthoclase, is occasionally seen.

Its variable optical properties: $\mathrm{n}_{\mathrm{x}}=1.522$ to 1.528 ; $\mathrm{n}_{\mathrm{y}}=1.528$ to $1.532 ; \mathrm{n}_{\mathrm{z}}=1.530$ to $1.538 ; 2 \mathrm{~V}_{\mathrm{x}}=40$ to $60^{\circ} ;$ seem to be related to slight zonal compositional changes or variations in the area taken up by two chemically differing submicroscopic fields. As a matter of fact, in two thin sections (specimens 3 and 4 ) parts of few phenocrysts exhibited typical plagioclase twin lamellae. Birrefringence, extinction angles and refractive indices indicate that such parts are constituted by albite grown in low temperature domains.

The normally homogeneous feldspar may be properly named cryptoperthitic orthoclase. It may have crystallized at a temperature above the solvus in the binary system $\mathrm{NaAlSi}_{3} \mathrm{O}_{8}-\mathrm{KAlSi}_{3} \mathrm{O}_{8}$, something between 700 and $1.000^{\circ} \mathrm{C}$, at 500 bars. Cryptoperthite may also be correlated to high temperature of formation together with speedy cooling after crystallization, two typical conditions in shallow pluton intrusions.

In Table 4, six chemical analyses of alkali feldspar show that clear homogeneous feldspar analyzed in nepheline syenite and in shonkinite exhibit similar average compositions: $\mathrm{Ab}$ 41.8/Or 55.8/An 2.24 and Ab 40.8/Or 55.7/An 3.5, respectively.

\section{Nepheline}

One of the last minerals to crystallize as limpid or turbid crystals, this mineral is present in all sampled P-A rocks. When clear, it exhibits prismatic shapes, idiomorphic only against feldspars. The two minerals may however appear as myrmekitic intergrowths or as turbid masses associated to analcite or zeolite.

In the system proposed by Donnay et al. (1959) the average P-A nepheline should be classified as medio potassic; $\mathrm{K} \sim 0.958$, where $\mathrm{K}$ is the number of potassium atoms replacing sodium (on the basis of 32 oxygens). P-A nepheline is also highly silicic $(\mathrm{Q} \sim 11.3)$, a character expected in the higher temperature assemblages of volcanic rocks where the accompanying feldspar is a homogeneous $\mathrm{Na}-\mathrm{K}$ feldspar.

The P-A nephelines have the following refractive indices: $\mathrm{n}_{\mathrm{e}} \sim 1.535 ; \mathrm{n}_{\mathrm{o}} \sim 1.540$; and birefringence $\mathrm{n}_{\mathrm{e}}-\mathrm{n}_{\mathrm{o}} \sim 0.005$.

Table 4 shows some chemical data for the $\mathrm{P}$-A nephelines.

\section{Analcite}

Analcite occurs as a rare primary mineral of late formation, detected in some P-A malignites and shonkinites. It is usually associated to turbid interstitial nepheline-feldspar aggregates.

Only one crystal (Table 5) was found suitable for probe analysis. When compared with analyses taken from the literature its composition reveals a very high $\mathrm{K}$ variety $\left(2.5 \% \mathrm{~K}_{2} \mathrm{O}\right)$. The fact indicates that the last liquid in the P-A magma were abnormally enriched in $\mathrm{K}$.

\section{Magnetite}

Together with apatite this is the first mineral to crystallize from the P-A basaltic magma. It occurs in the mafic rocks as scattered small octahedrons, sometimes modified by small scale dissolution patterns and biotite incrustations.

Magnetite exhibits a very high Ti content (Table 5) particularly in the more mafic samples. This fact would attest to the titaniferous character of the parental magma. 
Table 4. Chemical analyses of other mineral constituents of Pariquera-Açu rocks (wt \%).

\begin{tabular}{|c|c|c|c|c|c|c|}
\hline \multicolumn{7}{|c|}{ Alkali Feldspar } \\
\hline & \multicolumn{3}{|c|}{$\begin{array}{c}\text { In nepheline syenite } \\
\text { (9 analyses) }\end{array}$} & \multicolumn{3}{|c|}{$\begin{array}{c}\text { In shonkinite } \\
\text { (6 analyses) }\end{array}$} \\
\hline & Min & Max & Av & Min & Max & Av \\
\hline $\mathrm{SiO}_{2}$ & 64.91 & 65.50 & 65.21 & 64.07 & 65.38 & 64.88 \\
\hline $\mathrm{TiO}_{2}$ & 0.00 & 0.05 & 0.02 & 0.00 & 0.15 & 0.06 \\
\hline $\mathrm{Al}_{2} \mathrm{O}_{3}$ & 19.13 & 19.54 & 19.35 & 19.19 & 19.90 & 19.61 \\
\hline $\mathrm{Fe}_{2} \mathrm{O}_{3}$ & 0.01 & 0.30 & 0.10 & 0.00 & 0.17 & 0.06 \\
\hline $\mathrm{MnO}$ & 0.00 & 0.13 & 0.02 & 0.00 & 0.06 & 0.01 \\
\hline $\mathrm{MgO}$ & 0.00 & 0.02 & - & 0.00 & 0.02 & - \\
\hline $\mathrm{CaO}$ & 0.24 & 0.71 & 0.48 & 0.43 & 1.04 & 0.70 \\
\hline $\mathrm{Na}_{2} \mathrm{O}$ & 3.55 & 5.32 & 4.72 & 3.79 & 4.86 & 4.53 \\
\hline $\mathrm{K}_{2} \mathrm{O}$ & 8.59 & 11.42 & 9.58 & 8.66 & 10.36 & 9.41 \\
\hline $\mathrm{F}$ & 0.00 & 0.11 & 0.02 & 0.00 & 0.11 & 0.03 \\
\hline $\mathrm{BaO}$ & 0.00 & 0.49 & 0.12 & 0.00 & 0.52 & 0.28 \\
\hline $\mathrm{SrO}$ & 0.00 & 0.16 & 0.11 & 0.00 & 0.25 & 0.09 \\
\hline $\mathrm{Ab}$ & & & 41.8 & & & 40.8 \\
\hline Or & & & 55.8 & & & 55.7 \\
\hline \multirow[t]{4}{*}{ An } & & & 2.4 & & & 3.5 \\
\hline & \multicolumn{6}{|c|}{ Nepheline } \\
\hline & \multicolumn{3}{|c|}{$\begin{array}{c}\text { In nepheline syenite } \\
\text { (5 analyses) }\end{array}$} & \multicolumn{3}{|c|}{$\begin{array}{c}\text { In shonkinite } \\
\text { (3 analyses) }\end{array}$} \\
\hline & Min & Max & Av & Min & Max & Av \\
\hline $\mathrm{SiO}_{2}$ & 44.68 & 47.54 & 46.70 & 44.80 & 47.56 & 46.25 \\
\hline $\mathrm{TiO}_{2}$ & - & - & - & - & - & - \\
\hline $\mathrm{Al}_{2} \mathrm{O}_{3}$ & 32.44 & 33.15 & 32.66 & 31.24 & 32.85 & 31.94 \\
\hline $\mathrm{Fe}_{2} \mathrm{O}_{3}$ & 0.14 & 0.29 & 0.19 & 0.11 & 0.22 & 0.18 \\
\hline $\mathrm{MnO}$ & 0.00 & 0.16 & 0.04 & 0.00 & 0.09 & 0.03 \\
\hline $\mathrm{MgO}$ & 0.00 & 0.04 & 0.01 & 0.00 & 0.03 & 0.02 \\
\hline $\mathrm{CaO}$ & 0.78 & 1.10 & 0.92 & 0.97 & 1.02 & 0.99 \\
\hline $\mathrm{Na}_{2} \mathrm{O}$ & 14.14 & 15.78 & 14.98 & 12.62 & 15.53 & 14.48 \\
\hline $\mathrm{K}_{2} \mathrm{O}$ & 3.65 & 4.61 & 3.98 & 3.58 & 4.01 & 3.77 \\
\hline $\mathrm{F}$ & 0.00 & 0.34 & 0.13 & 0.00 & 0.29 & 0.10 \\
\hline $\mathrm{BaO}$ & 0.00 & 0.27 & 0.05 & 0.10 & 0.29 & 0.17 \\
\hline $\mathrm{SrO}$ & - & - & - & - & - & - \\
\hline $\mathrm{Cl}$ & 0.00 & 0.05 & 0.02 & 0.00 & 0.02 & 0.01 \\
\hline & & & age $\mathrm{Mc}$ & & & \\
\hline & & $\mathrm{mol} \%$ & & & & \\
\hline & & $\mathrm{mol} \%$ & & & & \\
\hline & & $\mathrm{mol} \%$ & & & & \\
\hline
\end{tabular}


Table 5. Microprobe chemical analyses (wt \%) of biotite, magnetite, ilmenite and analcite of the Pariquera-Açu rocks.

\begin{tabular}{|c|c|c|c|c|c|c|}
\hline & \multicolumn{6}{|c|}{ Biotite } \\
\hline & \multicolumn{3}{|c|}{$\begin{array}{c}\text { In nepheline syenite } \\
\text { (3 analyses) }\end{array}$} & \multicolumn{3}{|c|}{$\begin{array}{c}\text { In shonkinite } \\
\text { (4 analyses) }\end{array}$} \\
\hline & Min & Max & Av & Min & $\operatorname{Max}$ & Av \\
\hline $\mathrm{SiO}_{2}$ & 37.56 & 38.59 & 38.15 & 37.70 & 38.11 & 37.87 \\
\hline $\mathrm{TiO}_{2}$ & 5.08 & 6.39 & 5.75 & 6.65 & 8.45 & 7.67 \\
\hline $\mathrm{Al}_{2} \mathrm{O}_{3}$ & 12.38 & 12.57 & 12.50 & 12.82 & 13.16 & 12.97 \\
\hline $\mathrm{Fe}_{2} \mathrm{O}_{3}$ & 16.76 & 18.81 & 17.69 & 12.50 & 15.11 & 13.79 \\
\hline $\mathrm{MnO}$ & 0.12 & 0.22 & 0.17 & 0.00 & 0.21 & 0.05 \\
\hline $\mathrm{MgO}$ & 11.89 & 12.87 & 12.44 & 13.29 & 15.39 & 14.32 \\
\hline $\mathrm{CaO}$ & 0.00 & 0.00 & - & 0.00 & 0.03 & 0.01 \\
\hline $\mathrm{Na}_{2} \mathrm{O}$ & 0.36 & 0.49 & 0.44 & 0.38 & 0.49 & 0.42 \\
\hline $\mathrm{K}_{2} \mathrm{O}$ & 9.23 & 9.53 & 9.37 & 8.99 & 9.62 & 9.30 \\
\hline$F$ & 2.49 & 3.45 & 2.92 & 1.18 & 1.85 & 1.48 \\
\hline $\mathrm{BaO}$ & 0.00 & 0.04 & 0.01 & 0.00 & 0.25 & 0.12 \\
\hline $\mathrm{Cl}$ & 0.00 & 0.10 & 0.04 & 0.05 & 0.09 & 0.06 \\
\hline \multirow[t]{9}{*}{$\mathrm{H}_{2} \mathrm{O}$} & 2.37 & 2.78 & 2.61 & 3.17 & 3.50 & 3.36 \\
\hline & \multicolumn{4}{|c|}{ Magnetite } & \multicolumn{2}{|c|}{ Ilmenite } \\
\hline & \multicolumn{2}{|c|}{$\begin{array}{c}\text { In nepheline } \\
\text { syenite } \\
\text { (av. } 2 \text { an.) }\end{array}$} & \multicolumn{2}{|c|}{ In shonkinite } & \multicolumn{2}{|c|}{$\begin{array}{c}\text { In nepheline } \\
\text { syenite } \\
\text { (av. } 2 \text { an.) }\end{array}$} \\
\hline & & 19.55 & \multicolumn{2}{|c|}{22.27} & \multicolumn{2}{|c|}{51.34} \\
\hline & & 1.76 & \multicolumn{2}{|c|}{2.38} & \multicolumn{2}{|l|}{-} \\
\hline & & 48.52 & \multicolumn{2}{|c|}{49.84} & \multicolumn{2}{|l|}{1.88} \\
\hline & & 28.30 & \multicolumn{2}{|c|}{23.59} & \multicolumn{2}{|l|}{43.16} \\
\hline & & 0.91 & \multicolumn{2}{|c|}{0.72} & \multicolumn{2}{|l|}{1.68} \\
\hline & & 0.39 & \multicolumn{2}{|c|}{0.98} & 0.73 & \\
\hline
\end{tabular}

N. Contents of other oxides $\left(\mathrm{SiO}_{2}, \mathrm{Na}_{2} \mathrm{O}, \mathrm{K}_{2} \mathrm{O}, \mathrm{CaO}, \mathrm{BaO}, \mathrm{F}, \mathrm{Cl}\right)$ equal or under $0.1 \%$.

\begin{tabular}{|c|c|}
\hline & $\begin{array}{c}\text { Analcite } \\
\text { (1 analysis) }\end{array}$ \\
\hline $\mathrm{SiO}_{2}$ & 51.03 \\
\hline $\mathrm{TiO}_{2}$ & - \\
\hline $\mathrm{Al}_{2} \mathrm{O}_{3}$ & 26.84 \\
\hline $\mathrm{Fe}_{2} \mathrm{O}_{3}$ & - \\
\hline $\mathrm{MnO}$ & - \\
\hline $\mathrm{MgO}$ & 0.04 \\
\hline $\mathrm{CaO}$ & - \\
\hline $\mathrm{Na}_{2} \mathrm{O}$ & 10.46 \\
\hline $\mathrm{K}_{2} \mathrm{O}$ & 2.25 \\
\hline $\mathrm{F}$ & 0.01 \\
\hline $\mathrm{BaO}$ & - \\
\hline SrO & - \\
\hline $\mathrm{Cl}$ & - \\
\hline $\mathrm{H}_{2} \mathrm{O}$ & 8.05 \\
\hline Total & 98.68 \\
\hline
\end{tabular}




\section{Ilmenite}

Only one crystal tablet was analyzed with the microprobe (Table 5). No paragenetic relation has been possibly established.

\section{Apatite}

In relatively stout and round isolated prisms, apatite is the common accessory mineral in all rock types. No chemical analysis has been procured and commented.

\section{Olivine}

This is the first silicate mineral to crystallize in the P-A magma. It may be found isolated or included in clinopyroxene, quite fresh or totally replaced by chlorite and/or serpentine, idiomorphic or xenomorphic (by partial corrosion or dissolution). No microprobe analyses were taken but optical determinations in parts of crystals confirm its homogeneity: $\mathrm{n}_{\mathrm{x}}=1.682(0.003) ; \mathrm{n}_{\mathrm{y}}=1.705$ (0.003); $\mathrm{n}_{\mathrm{z}}=1.722(0.003) ; 2 \mathrm{~V}_{\mathrm{x}}=87^{\circ}\left(5^{\circ}\right)$.

\section{Biotite}

The last mafic primary mineral to crystallize in the P-A shonkinitic magma is a biotite with very high $\mathrm{TiO}_{2}$ content (up to $8.45 \%$ in a shonkinite sample, Table 5), which is responsible for its deep red color.

The crystallization of this Ti-biotite began after the cessation of magnetite, olivine and most of the clinopyroxenes. As a matter of fact, inclusions of biotite into border zones of clinopyroxenes show that final pyroxenes and initial biotite crystallized together.

Red biotite is also found as belts or palisades of small flakes surrounding magnetite and olivine. It can also replace clinopyroxene along cleavage or fractures, due to deuteric action.

Some of its optical properties: $\mathrm{n}_{\mathrm{z}} \sim 1.685,2 \mathrm{~V}_{\mathrm{x}}=28-33^{\circ}$, $\mathrm{v} \gg \mathrm{r}$ and pleochroism; $\mathrm{x}=$ light orange, $\mathrm{y}=$ orange red, $\mathrm{z}=$ red, place the mineral, properly, in the field of the titanbiotite.

As compared with those from shonkinite, iron contents of biotite from nepheline syenite is significantly higher. This data illustrates the well known process of iron enrichment in mineral phases of evolved igneous rocks.

\section{Hornblende}

The hornblende found in small amounts in part of the $\mathrm{P}-\mathrm{A}$ shonkinitic rocks is quite probably the Ti-hornblende, kaersutite.

Its distinctive optical properties are: $\mathrm{n}_{\mathrm{x}}=1.688 ; \mathrm{n}_{\mathrm{y}}=1.705$; $\mathrm{n}_{\mathrm{x}}=1.715 ; \mathrm{n}_{\mathrm{z}}-\mathrm{n}_{\mathrm{x}}=0.027$. Pleochroism $\mathrm{x}=$ yellow, $\mathrm{y}=$ red and $\mathrm{z}=$ deep red; $\mathrm{z} \wedge \mathrm{c}=12^{\circ}$.

The mineral is coeval with biotite and may appear either as isolated individuals or as an overgrowth on clinopyroxene.

\section{COMMENTS ON THE HISTORY OF THE P-A INTRUSION}

The P-A body seems to correspond to a small magma chamber shaped at intermediate crustal levels during the ascension of a mantle-derived magma. The cross section in Figure 1 displays the author's conception of ring dykes with steep inward deeps. The undeformed contacts with the enveloping rocks show that they occupied tensile fractures. The internal sub-horizontal flow lines can be interpreted as minor intrusions from a sheet-like magma during a possible cauldron subsidence.

The slight compositional variations within the mafic body would indicate that there may have occurred crystal-liquid fractionation extensive enough to produce salic differentiates. Upwardly segregated phonolitic magma would then preferably erupt as more mafic magmas, left behind in the source chamber.

For the P-A potassic mafic magma, some hypotheses of origin might be advanced (Hall, 1987):

a. melting of mantle material abnormally rich in $\mathrm{K}$;

b. fractionation of basalt, picrite or kimberlitic magma;

c. zone refining of basaltic magma;

d. contamination of basalt, nephelinite or carbonatite magma by either granitic or sedimentary material.

Detailed trace elements and isotope chemical analyses should be required in order to test the applicability of any of the above ideas. In the absence of such data and keeping in mind the compositional contrasts with the neighboring younger Na-rich alkalic intrusion, one would be led to believe that the high $\mathrm{K}$ characteristics of the P-A magma might reflect some degree of crustal contamination in active magma margins. Nevertheless, geochronological determinations made by Machado Jr. (1998) on P-A shonkinites established a $R_{0}=0.70520$, a value consistent with mantle magma derivation and incompatible with crustal contamination. The intrusion age, as indicated by radiometric determination made by same author is $142.1 \pm 7.3 \mathrm{Ma}$, a value close to the Early Cretaceous ages obtained for the neighboring alkaline complexes of Jacupiranga and Juquiá and basaltic dykes of the Guapiara lineament and coastal region. 
Gibson et al. (1995) forward the idea that "when the subcontinental lithospheric mantle undergoes heating and/or extension, some of the earliest mafic melts to be generated are those rich in volatiles and potassium". Experimental studies suggest that small degrees of partial melting of a phlogopite-bearing peridotite at depths below the level of amphibole stability might produce a high $\mathrm{K}_{2} \mathrm{O}$ partial melting (Wilson, 1987).

Kaul et al. (1982) and Kaul (1984) contend that the Serra do Mar intrusive suite composed by 16 anorogenic K-rich granites, many of which of peralkaline character, appeared at the end of Proterozoic and onset of the Eopaleozoic about $500 \mathrm{Ma}$ ago, when distensional forces (in the line proposed by Bailey, 1983) induced intracontinental rifting along a NEE-SWW direction at the southeast margin of the Paraná Basin.

Almeida (1983) called the attention to the existence of 12 mesozoic alkalic provinces in the meridional portion of
South America and their relationship with regional structures such as flexures and rifts. The alcalic intrusions of the Serra do Mar province are spread along a distinct lineament (Figure 4) that can be envisaged as the NEE-SWW of a three-rift system formed by a southward N-S arm and the failed arm of the Ponta Grossa arch. The P-A intrusion is positioned close to the triple junction.

A Mesozoic reactivation of Precambrian lines of weakness at the time of the separation of continents could give an opportunity for the ascension of alkaline mantle magmas beginning with the K-rich types.

It is conceivable that along the southern Brazilian coast, a renewed rifting, triggered new alcalic magmatism, $370 \mathrm{Ma}$ after the first granitic manifestation. Concerning such long elapsed time it is worth noticing that periods of hundred of million years have been claimed for riftings such as observed in the Precambrian Gardar Province (Upton and Emeleus, 1987).

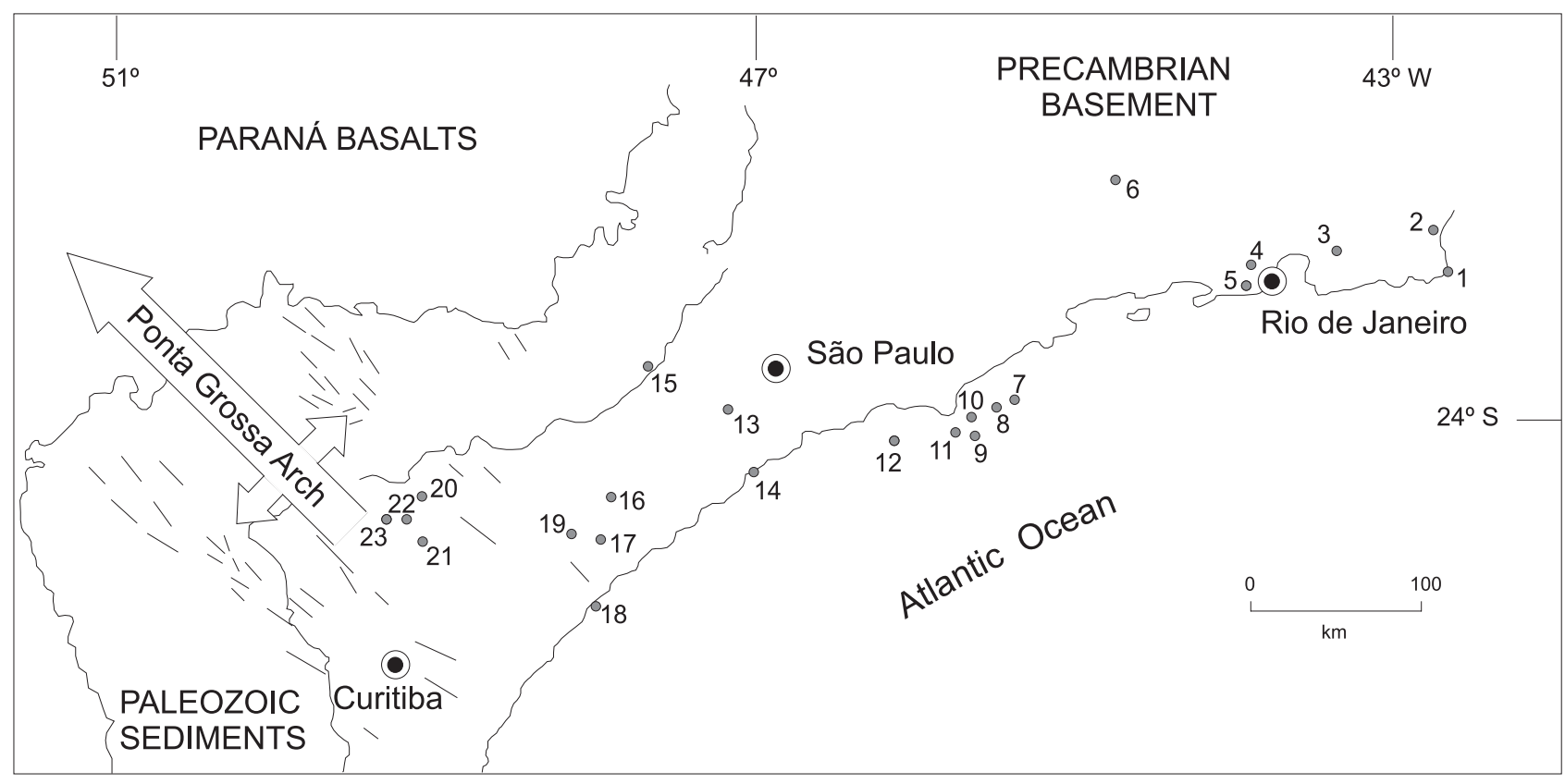

Figure 4. Location of the main alkaline intrusions known to occur in the "Província da Serra do Mar". 1. Morro de São João. 2. Ilha de São Francisco. 3. Rio Bonito. 4. Tinguá. 5. Pico do Marapicu. 6. Itatiaia. 7. Ilha de Vitória. 8. Ilha de Búzios. 9, 10, 11. Ilha de São Sebastião. 12. Ilha do Montão de Trigo. 13. Piedade. 14. Itanhaém. 15. Ipanema. 16. Juquiá. 17. Pariquera-Açu. 18. Cananéia. 19. Jacupiranga. 20. Itapirapuã. 21. Tunas. 22. Banhadão. 23. Barra do Teixeira. NW-SE dashes represent basaltic dykes of the Guapiara and São Jerônimo - Curiúva lineaments on both sides of the Ponta Grossa arch. 


\section{CONCLUSIONS}

Field survey in the region of Pariquera-Açu (P-A), São Paulo, Brazil, exposed a cordiform mafic potassic plutonic body intruded in phyllitic country rocks. A cone-shaped intrusion enveloped by sub-vertical boundaries is implied. Internal structures point to the presence of horizontal to low-angle beds formed by flow or crystal accumulation. A peripheral breccia is interpreted as a separate body of quartz phyllite cataclasite.

Except for restricted alkali diabase dykes, all collected and studied samples are rocks of the pyroxenite-shonkinitemalignite-nepheline syenite magma series. They contain variable amounts of idiomorphic clinopyroxene, olivine and magnetite set in a light-colored basis composed essentially by orthoclase and nepheline. No plagioclase is present.

Chemical analyses stress the distinctly potassic character of the P-A rocks. Their mineral components are also chemically and microscopically distinguished and reinforce that assumption.

The evolution of the P-A magma is also commented. It is accepted that it is mantle-derived and ascended during a Mesozoic reactivation of a three-rift system present in southern Brazil. K-rich magma would be the initial type in a sequence of injections.

\section{REFERENCES}

ALMEIDA, F. F. M. Relações tectônicas das rochas alcalinas mesozóicas da região meridional da Plataforma SulAmericana. Revista Brasileira de Geociências, v. 13, n. 3, p. 139-158, 1983.

BAILEY, D. K. The chemical and thermal evolution of rifts. Tectonophisics, v. 94, p. 587-597, 1983.

BECCALUVA, L.; BARBIERI, M.; BORN, H.; BROTZU, P.; COLTORTI, M.; CONTE, A.; GARBARINO, C.; GOMES, C. B.; MACCIOTA, G.; MORBIDELLI, L.; RUBERTI, E.; SIENA, F.; TRAVESSA, G. Fractional crystallization and liquid immiscibility processes in the Alkaline-Carbonatite complex of Juquiá (São Paulo, Brazil). Journal of Petrology, v. 33 n. 6, p. 1371-1404, 1992.

BORN, H., O Complexo alcalino de Juquiá. In: CONGRESSO BRASILEIRO DE GEOLOGIA, 25., 1971, São Paulo. Anais... São Paulo: SBG, 1971. v. 1, p. 223-225.

DEER, W. A.; HOWIE, R. A.; ZUSSMAN, J. An introduction to the rock-forming minerals. Harlow: Longman. $1993.695 \mathrm{p}$.

DONNAY, G.; SCHAIRER, J. F.; DONNAY, J. D. H. Nepheline solid solution. Mineralogical Magazine, v. 32, n. 245, p. 93-109, 1959.

FERREIRA, F. J. F.; ALGARTE, J. P.; THEODOROVICS, A.; MONMA, R.; MARTINS, F.A. G.; TASSINARI, C. G. C.;
SILVA, R. B.; RODRIGUES, E. P.; COUTINHO, J. M. V.A intrusão alcalina de Pariquera-Açu. In: SIMPÓSIO REGIONAL DE GEOLOGIA, 6., 1987, Rio Claro. Atas... Rio Claro: SBG-Núcleo de São Paulo, 1987. v. 1, p. 159-171.

FERREIRA, F. J. F.; ALGARTE, J. P. O comportamento aeromagnético-cintilométrico das principais rochas alcalinas do Estado de São Paulo e Paraná. In: SIMPÓSIO REGIONAL DE GEOLOGIA, 2., 1979. Atas... Rio Claro: SBG-Núcleo de São Paulo, 1979. v. 2, p. 195-208.

GIBSON, S. A.; THOMPSON, R. N.; LEONARDOS, O. H.; DICKIN, A. P.; MITCHELL, J. G. The Late Cretaceous impact of the Trindade mantle plume: evidence from large volume mafic potassic magmatism in SE Brazil. Journal of Petrology, v. 36, n. 1, p. 189-229, 1995.

GOMES, C. B.; DUTRA, C. V. Some geochemical features of the alkaline rocks of Itapirapuã, São Paulo, Brazil. Anais da Academia Brasileira de Ciências, v. 42, n. 3, p. 521-534, 1970.

HALL, A. Igneous Petrology. Essex, England: Longman, 1987.572 p.

JOHANNSEN, A. A descriptive petrography of the igneous rocks. Chicago: University of Chicago Press, v. 4, 1938. $520 \mathrm{p}$.

IRVINE, T. N. Terminology for layered intrusions. Journal of Petrology, v. 23, p. 95-113, 1982.

KAUL, P. F. T.; ISLER, R. S.; FERNANDES, E.; BONOW, C. V.; COITINHO, B. L. Suite Intrusiva Serra do Mar. Florianópolis: Projeto Radam Brasil, 1982. 18 p. Relatório Interno, 540-G.

KAUL, P. F. T. Significado dos granitos anorogênicos da suite intrusiva Serra do Mar na evolução da crosta sulsudeste do Brasil no âmbito das folhas SG-22-Curitiba e SG-23-Iguape. In: CONGRESSO BRASILEIRODE GEOLOGIA, 33., 1984. Anais... Rio de Janeiro: SBG, 1984. v. 6, p. 2815-2821.

LE BAS, M. J. Carbonatite-Nephelinite volcanism: an African case history. In: The nomenclature of alkaline igneous rocks. London: J. Wiley and Sons, 1977. p. 24-38.

SORENSEN, H. The alkaline rocks. London: J. Wiley and Sons, 1974.

MACHADO JUNIOR, D. L. Geochronologia Rb/Sr no maciço alcalino de Pariquera-Açu, SP. In: CONGRESSO BRASILEIRO DE GEOLOGIA, 40., 1998, Belo Horizonte. Anais... Belo Horizonte: SBG, 1998. p. 466.

MIDDLEMOST, E. A. K. The basalt clan. Earth Science Reviews, v. 11, p. 337-364, 1975.

MORBIDELLI, L.; GOMES, C. B.; BROTSU, P.; D’ACQUARICA, S.; GARBARINO, C.; RUBERTI, E.; TRAVERSA, G. The Pariquera-Açu K-alkaline complex and Southern Brazil lithospheric mantle source characteristics. Journal of Asian Earth Sciences, v. 18, p. 129-150, 2000. 
POLDERVAART, A.; PARKER, A. B. The crystallization index as a parameter of igneous differentiation in binary variation diagram. American Journal of Science, v. 262, p. 281-289, 1964.

UPTON, B. G. J.; EMELEUS, C. H. Mid-Proterozoic alkaline magmatism in Southern Greenland: the Gardar Province. In: Fitton, J. G.; Upton, B. G. J. (Ed.). Alkaline igneous rocks. Oxford: Geological Society of London, 1987. p. 449-471. (Geological Society Special Publication, 30).

STRECKEISEN, A. To each plutonic rock its proper name. Earth Science Reviews, v. 12, p. 1-33, 1976.

THORNTON, C. P.; TUTTLE, O. F. Chemistry of igneous rocks. 1- Differentiation index. American Journal of Science, v. 258, p. 664-684, 1960.

WILSON, M. Igneous petrogenesis. London: Unwin Hyman, 1991. Chapter 12, p. 375-416. 